Abstracta Iranica Iranica

Revue bibliographique pour le domaine irano-aryen

Volume 32-33 | 2013

Comptes rendus des publications de 2009-2010

\title{
Peter Edwell. Between Rome and Persia. The Middle Euphrates, Mesopotamia and Palmyra Under Roman Control
}

\section{Vito Messina}

\section{(2) OpenEdition \\ 1 Journals}

\section{Electronic version}

URL: http://journals.openedition.org/abstractairanica/40486

DOI: $10.4000 /$ abstractairanica.40486

ISSN: 1961-960X

Publisher:

CNRS (UMR 7528 Mondes iraniens et indiens), Éditions de l'IFRI

\section{Printed version}

Date of publication: 1 December 2013

ISSN: 0240-8910

\section{Electronic reference}

Vito Messina, « Peter Edwell. Between Rome and Persia. The Middle Euphrates, Mesopotamia and Palmyra Under Roman Control », Abstracta Iranica [Online], Volume 32-33 | 2013, document 151, Online since 01 July 2016, connection on 03 October 2020. URL : http://journals.openedition.org/ abstractairanica/40486 ; DOI : https://doi.org/10.4000/abstractairanica.40486

This text was automatically generated on 3 October 2020.

Tous droits réservés 


\title{
Peter Edwell. Between Rome and Persia. The Middle Euphrates, Mesopotamia and Palmyra Under Roman Control
}

\author{
Vito Messina
}

\section{REFERENCES}

Peter Edwell. Between Rome and Persia. The Middle Euphrates, Mesopotamia and Palmyra Under Roman Control. London \& New York, 2008, 320 p., ill. (Routlege Monograhps in Classical Studies).

1 Peter Edwell outlines the history of the Middle Euphrates in the context of the dualism, which seems to emerge from the evidence to date, between Rome and the eastern empires, Parthian and Sasanian. This dualism, often simplified as a conflict, is gradually becoming clear thanks to modern studies of history. Using different sources (literary, epigraphic and archaeological), the author lays special emphasis on the regional importance of the Euphrates River for Palmyrene and Mesopotamia.

2 Given that Europos Dura and Palmyra are considered to be the leading sites in the region, the author focuses on the historical records and archaeological data that help us place them in the broader context of a regional study, in particular during the centuries AD. This leads him to raise questions about Rome's political and military presence in the region. The book has five chapters. The first chapter, "Rome on the Euphrates and in Mesopotamia, c. 65 BC-c. 200 AD", describes the Euphrates as a boundary between Rome and Parthian interests; and the second, "Palmyra and Rome from the mid-first century BC to the third century AD", focuses on Palmyra's role. In the third, "Roman military organization of the middle Euphrates in the third century $A D$ ", the author locates fortifications along the Euphrates known from epigraphic 
sources, and points to their importance (not just for defensive purposes) in the landscape. The fourth chapter, "Dura Europos on the middle Euphrates in the Parthian and Roman periods", reviews the history of Europos Dura in the context of Seleucid, Parthian and Roman control of the city, and reconsiders the office of Dux Ripae and the purpose of Rome's military presence. The conflict between Rome and the Sasanian Empire is the core of the fifth chapter, "Conflict between Rome and Sasanian Persia involving the middle Euphrates, Mesopotamia and Palmyra, AD 224-258”.

\section{AUTHORS}

\section{VITO MESSINA}

Università di Torino 